\title{
Book of the Year
}

\section{A fortunate man}

\author{
JOHN STALLWORTHY
}

If I had to nominate a book of the year it would be a fascinating, and frequently exciting, autobiography of a remarkable surgeon. It is hard to imagine that the $B M F$ has ever reviewed a comparable book, and I am privileged to have been entrusted with the formidable task. However inadequate the result, its deficiency will not be due to lack of admiration of the many varied and great contributions Sir Geoffrey Keynes has made, both directly and indirectly, during his long and most distinguished professional life, nor of the clarity with which his story has been told. The failure will be mine.

The choice of title from William Blake's The Four Zoas,

"Unbar the Gates of Memory: look upon me

Not as another, but thy real Self. I am thy Spectre,"

was a happy one. Not only are the gates unbarred but the host of memories as they pass through are chronicled with the skill and precision of the master bibliographer. In addition, they are given life by the human interest, drama, historical importance, and recurring humour of their presentation. It is not surprising that Blake provided the title. In 1907 he was unknown to the young Cambridge undergraduate whose attention was arrested, whose imagination was fired, and whose life was changed by two prints from Illustrations of the Book of $\mathcal{F}_{\mathrm{ob}}$ displayed in the window of a Trinity Street bookshop. Over 70 years later GLK wrote:

"My friends had often thought that literature and bibliography were my first loves, with surgery as a background, in reality it had been the other way round. My most intense interest had been in the science and practice of surgery, with a parallel delight in literature and in particular the life and work of William Blake to keep alive in my mind the value of imagination in a material worldan important background to a profession which might lead to a slight twist of inhumanity."

In the intervening years-in spite of serving throughout two world wars as a surgeon and the heavy demands of surgical practice between them-when he returned in 1945 from his RAF duties as surgeon acting Air Vice-Marshal to the coveted post of senior surgeon to Barts Keynes was already a world authority on Blake. His internationally famous library included a priceless collection of Blake treasures; he himself was a major contributor to the literature on Blake; in 1931 his great stimulus to British ballet was performed for the first time at the Cambridge Theatre in London. It was "Job: A Masque for Dancing," based on Blake's Vision of the Book of fob. In 1957 he unveiled the bronze head of Blake by Epstein in Poets' Corner of Westminster Abbey, and on returning from the second world war he initiated the William Blake Trust as a non-profit educational charity because of his anxiety that the unique coloured copy of Blake's Jerusalem with its 100 etched

\section{Headington, Oxford OX3 8TA}

SIR JOHN STALLWORTHY, FRCS, FRCOG, emeritus professor of obstetrics and gynaecology plates might be sold abroad. The trust produced 500 copies of the Jerusalem facsimile of the finest possible quality on paper identical with that used by Blake.

The association of vision with the knowledge of where to find perfectionists able to transform dreams into reality and the ability to enlist their support are shown repeatedly throughout this book as one of the author's great attributes. Space in what must be primarily a medical review does not permit more than passing reference to many of the varied contributions to literature and art made by this surgeon, who was honoured by both Oxford and Cambridge Universities with an Honorary Doctorate of Letters and was elected President of the Bibliographical Society of London; Chairman of the National Portrait Gallery; Harveian Orator of the Royal College of Physicians of London; and in his 94th year an Honorary Fellow of the British Academy. In medical parallel with these honours was a knighthood conferred "for surgical distinction" in 1953; Sims Travelling Professor to Canada and southern Africa in 1956; honorary fellowships of the Royal College of Physicians of London, the Royal Society of Medicine, and the Royal College of Obstetricians and Gynaecologists, to mention but a few of the tributes paid by his colleagues to a giant in the profession.

\section{Nursery of promise}

Geoffrey's potential interest in medicine was observed and recorded by his mother when she found him on the nursery floor studying diagrams of the circulation of blood at the age of 3. At about the same time she found her elder son Maynard, then aged 6, asking such questions as "Who invented time?" "How did things get their names ?" and commenting "Just now my brain is wondering how it thinks. It ought to know." What a nursery of promise, later to be richly fulfilled in so many spheres of life by two remarkable men! In his long professional life GLK delivered a Vicary lecture on "The Portraiture of William Harvey 1578-1657" to the Royal College of Surgeons and the Barber Surgeons in 1948, had the rare distinction as a surgeon of being Harveian Orator (the 254th) at the Royal College of Physicians of London in 1958, and published his Life of William Harvey in 1966. His nursery introduction to Harvey's epic discovery led to his greater interest in Harvey the man and his contributions to science and medicine, until he won recognition as a world authority on this subject, in 1967 addressing the Royal Society on the subject of Bacon, Harvey, and the foundation of the society. Keynes argued that Harvey and Gilbert, not Bacon, had inspired acceptance of experimental science and the creation of the Royal Society. It was fitting, therefore, that when the missing portrait of Harvey as a young man was recovered from a collector's gallery in America it should be hung in the National Portrait Gallery with a photograph of Sir Geoffrey alongside. The saga of this event is exciting, and, dramatised for the stage, a film, or television, could be a superb detective thriller of historical interest. 
The scenario would open with a 3-year-old lad on a nursery floor entranced by pictures of the human heart and circulation, followed by an early and rapidly developing interest in literature and art, stimulated at Rugby by his close friendship with the young Rupert Brooke. This initiated bibliographical and collector instincts, which flourished at Cambridge, where he took the decision to be a surgeon trained at St Bartholomew's Hospital. This goal, like so many others, was achieved, although his examiners for the Primary Fellowship (who may have been relatively illiterate) decided that specialised knowledge of William Blake, John Donne, and Sir Thomas Browne did not qualify a candidate to pass in anatomy; he was failed at this first attempt.

On returning to Barts as an assistant surgeon after the 1918 war Keynes's interest in William Harvey grew. The first edition of his Bibliography of Harvey was published in 1928 and that year he visited the Harvey Chapel of the Hempstead church in Essex, where Harvey was interred. This was a medical pilgrimage in connection with the celebration by the Royal College of Physicians of London of the tercentary of the publication of De Motu Cordis. Accompanying him was a senior Barts surgeon and friend Sir D'Arcy Power, who had published a short bibliography of Harvey in 1897. Motoring back to London together they stopped at Rolls Park, near Chigwell, to visit the widow of a descendant of William Harvey's younger brother Eliab. During tea GLK observed eight portraits mounted together on one wall of the hall in plaster surrounds and was told that they were copies of family portraits and of little interest. Twenty years later, when preparing the Vicary lecture Sir Geoffrey remembered the visit to Rolls Park in 1928 and determined to study the eight "copies" of Harvey family portraits more closely. The house was derelict after bomb damage in the war and due to be demolished, but permission to visit was given. The lofty hall with its portraits was shuttered and dark but on a second visit, aided by a caretaker, ladder, and candle, he found the only surviving portrait of William Harvey as a young man. The others were of his father and five of his seven brothers. Two portraits had been removed. The owner agreed to the remaining six being taken to the National Portrait Gallery for cleaning and framing before being exhibited on loan to the Royal College of Physicians of London for 10 years, with a promise that it would have the first option to purchase the portrait of William Harvey if ever it was sold. For the details of the drama which followed the disappearance of the picture you must read the book, or wait for its dramatisation. The success story is written superbly.

\section{Surgery of the breast and thymus}

The surgeon who achieved so much in his chosen specialty makes modest and relatively brief references to this aspect of his life, apart from those recurring occasions when there is inevitable intermingling with other interests such as literature and art. A short chapter of eight pages deals with his successful challenge to the then orthodox treatment of breast cancer. His research into the results of radical surgery, and influenced by the beauty of the human body as portrayed by Blake, caused him to stop performing the radical Halsted operation and to advocate and practise a combination of the much less mutilating local removal of the tumour with interstitial irradiation at the operation site. With new, more precise radiation techniques now available this concept may even now not have been fully explored. A second 12-page chapter records concisely his major contribution to the surgery of the thymus, and its implication to the treatment of myasthenia gravis, with only passing reference to his wide experience of thyroidectomy. This followed his association with another master surgeon Sir Thomas Dunhill at Barts and at the endocrine clinic he founded in New End Hospital Hampstead with GLK and Jack Piercy as his assistants. Just as there was powerful opposition in America and elsewhere to Keynes's work on breast cancer so there was to his pioneer approach to thymectomy, but in both cases this opposition was later followed by acceptance. Interestingly, at the recent BMA Clinical Meeting in San Diego tributes were paid to Geoffrey Keynes as a pioneer in the modern concept of the treatment of breast cancer.

The history of medicine and surgery records that opposition to surgical pioneers is not unusual and it is interesting to note that one of the two surgeons acknowledged by Sir Geoffrey as having most influenced and guided the development of his surgical skills was a pioneer who was first rejected, even at Barts. This was the Australian, Sir Thomas Dunhill. The excellent results he reported from Melbourne in the treatment of toxic goitre by thyroidectomy were not believed in London. $\mathrm{He}$ shared this unenviable distinction with some of his New Zealand colleagues who were also widely experienced and skilled in the same techniques. "Can any good thing come from Nazareth ?" was the reaction of the unbelievers. But when the gentleness of Dunhill's perfected technique, and the results it achieved, were seen in London another great Barts surgeon, Sir George Gask, was responsible for Dunhill's appointment to the surgical staff of that great hospital. He was then a Barts man, and surgery, Saint Bartholomew's, and GLK all reaped the benefit. Lord Moynihan also exerted a powerful influence over GLK, whom he selected as his assistant in London. In return, his patients, and he himself, benefited from his young colleague's expertise as pioneer in blood transfusion, as did many of the gravely wounded and shocked soldiers transferred to "moribund" wards in the first world war when Lieutenant Keynes, RAMC, was instrumental in restoring them to life.

The question most readers of this delightful book will ask is how can one man, even when blessed with such a diversity of talents, achieve so much and still be alive and able to write this book at the age of 94 ? He answers this question himself in chapter 15:

"There is always time for something you really want to do if you don't waste any. . . . Punctuality for all professional engagements is essential; this depends on good organisation, which affects everything else throughout an active day. Such a day should not infrequently be concluded at the theatre or the ballet, for there is always time, too, for life's major enjoyments."

For the reviewer reading this book has been one of these. It is hard to imagine any reader who will not be interested in the memories this great man records so vividly of legendary figures and the giants of yesterday in so many professions. Most will be captivated as they read, and many will remember with deep gratitude the personal help and encouragement they received so generously from Geoffrey Keynes when he recognised their undiscovered talents as writers, poets, bibliographers, sculptors, or painters. Their gratitude will be mingled with deep affection and the hope that as this grand old man contemplates his garden and his life from the shades of the beautiful tulip tree at Lammas House, the memories which crowd in through the gates will bring him peace and happiness.

The Gates of Memory. Geoffrey Keynes. (Pp 428; £12.50.) Oxford University Press. 1981.

ONE HUNDRED YEARS AGO One of the principal arguments of vegetarians is that, by following the precepts of Pythagoras, we should avoid many diseases, and especially the gout. It would seem, however, that vegetable diet is not always efficacious in the case of parrots, which, although incontestable vegetarians, yet are afflicted with gout. At one of the recent meetings at the Sociéte de Biologie, $M$ Megnin showed an unfortunate parroquet which had succumbed to gout; the digital and tarsal joints were surrounded by tophi formed of urates. Similar lesions are not uncommon in cage-birds, which can only take but very little exercise in comparison with their habits in a state of nature. (British Medical fournal, 1881.) 